\title{
IDENTIFIKASI SEBARAN DAN KEDALAMAN PASIR BESI DI DAERAH PANTAI SAMAS DUSUN NGEPET DESA SRIGADING KAB.BANTUL DENGAN MENGGUNAKAN METODE GEOFISIKA MAGNETIK, DAN GEOLISTRIK
}

\author{
Sismanto*, Yuris Sutanto, Radjabal Akbar and Syamsul Fala Alaidin
}

\begin{abstract}
Ringkasan
Indonesia kaya akan hasil mineral tambang salah satunya adalah pasir besi, keberadaan pasir besi terdapat juga di pantai selatan Jawa. Kenampakan pasir besi tersebut juga banyak berada di pantai selatan Kulon Progo dan Bantul. Tujuan penelitian ini adalah untuk mengetahui kontras anomali besaran fisika atas keberadaan pasir besi dengan menggunakan metode geofisika. Kontras anomali ini digunakan untuk mengidentifikasi penyebaran dan memperkirakan ketebalan pasir besi di daerah studi.

Penentuan kontras anomali dengan menggunakan metode magnetik, dan metode geolistrik. Metode magnetik sendiri bertujuan untuk melihat kontras anomali medan magnet total yang disebabkan oleh kontras susceptibilitas batuan yang digunakan untuk mendapatkan arah sebaran pasir besi. Metode geolistik memanfaatkan besaran resistivitas/konduktivitas pada perlapisan sehingga dapat memperkirakan kedalaman atau ketebalan lapisan pasir besi tersebut.

Hasil interpretasi peta anomali medan magnet tital, mencirikan sebaran pasir besi memiliki nilai 86,4 $\mathrm{nT}$ sampai 1092,2 nT dan menurut hasil tumpang tindih (overlay) peta geologi dengan peta anomali medan magnet tootal reduksi ke kutub terlihat bahwa anomali magnetik hampir merata. Hasil interpretasi geolistrik sounding menunjukkan bahwa penyebaran pasir besi dominan mengarah ke timur dengan nilai resistivitas $300 \Omega m-$ $1000 \Omega m$ dan kedalaman pasir besi berada di $5-20 m$ dibawah permukaan. Estimasi cadangan pasir besi pengukuran resistivitas dengan luas wilayah $1 \mathrm{~km}^{2}$ adalah sebesar $54.237 .500 \mathrm{~m}^{3}$
\end{abstract}

Kata Kunci : Pantai Goa Cemara, Pasir Besi, metode Geolistrik dan magnetik

\section{Abstract}

Indonesia is rich in mineral mining, one of wich is iron sand, the presence of iron sand is also in the south coast of Java. Tge appearance of iron sand is widely located in the southern coast of Kulon Progo and Bantul. The purpose of this research is to know the anomaly of the existence of iron sand by using geophysical method. This anomaly is used to identify the spread and estimate the thickness of iron sand in the study area.

Determination of anomaly by using magnetic and geoelectric methods. The magnetic method itself aims to see the total magnetic field anomaly caused by the contrast of rock susceptibility used to obtain the direction of the spread of rion sand. The geoelectric method utilizes the resistivity or conductivity parameter of the layers to estimate the depth or thickness of the iron sand layer.

The result of interpretation of the total magnetic field anomaly map, characterize the distribution of iron sand has value $86,4 n T$ to $1092,2 n T$ and according to result of overlay of geological map with map of magnetic field anomaly total reduction to pole seen that magnetic anomaly alomst evenly. The results of the sounding geoelectric interpretation indicate that the dominant iron sand spread leads to the east with a resistivity value of $300 \Omega m-1000 \Omega m$ abd the depth of iron sand is at $5-20 \mathrm{~m}$ below the surface. Estimated reserves of iron sand resistivity measuremets with an area of $11 \mathrm{~km}^{2}$ are $53,237,500 \mathrm{~m}^{3}$.

Keywords: Goa Cemara Beach; Iron Sand; Geoelectrics and magnetics methods 


\section{Pendahuluan}

Indonesia kaya akan hasil mineral, salah satunya pasir besi. Penyebaran pasir besi membentang dari bagian barat pulau Sumatera hingga Sulawesi. Pulau Jawa sendiri dikenal memiliki banyak potensi pasir besi yang berada di bagian selatan pulau Jawa. Kegunaan pasir besi itu sendiri digunakan untuk material penyusun Industri besi dan baja [1]. Proses terbentuknya pasir besi sendiri berasal dari hasil produk vulkanik. Material vulkanik tersebut terdeportasi menuju pantai melewati sungai dan berakhir di lautan, terkikis dan terdeportasi menuju bibir pantai dan terendapkan. Proses ini bisa juga disebut dengan proses sedimenter. Proses pengendapan ini termasuk ke dalam pengendapan bijih besi sekunder [3]. Salah satu area yang kaya akan hasil pasir besi ialah Pantai Samas dan Pantai Goa Cemara yang berada di bantul, Yogyakarta. Penyebaran, deposit, kedalaman serta estimasi volume pasir besi dapat dihitung menggunakan metode geolistrik.

\section{Geologi daerah Penelitian}

Van Bemmelen, 1949 membagi Jawa Tengah menjadi enam zona fisiografi, yaitu Gunung Api Kuarter, Dataran Aluvial Utara Jawa, Antiklinorium Serayu Utara, Kubah dan Punggungan pada Zona Depresi Tengah, Zona Deprei Tengah dan Pegunungan Selatan. Berdasarkan pembagian tersebut daerah bantul sebagian besar termasuk ke daerah zona depresi tengah dan sebagian lagi masuk ke pegununfan selatan (Gambar 1). Zona pegunungan selatan dapat dibagi menjadi tiga subzona, yaitu Subzona Baturagung, Subzona Wonosari dan Subzona Gunung Sewu [2]. Subzona Baturagung terutama terletak di bagian utara, namun membentang dari barat (tinggian G. Sudimoro, $\pm 507 \mathrm{~m}$, antara Imogiri-Patuk), utara (G. Baturagung, $\pm 828 \mathrm{~m}$ ), hingga ke sebelah timur (G. Gajahmungkur, $\pm 737 \mathrm{~m}$ ). Di bagian timur ini, Subzona Baturagung membentuk tinggian agak terpisah, yaitu gunung Punggung $( \pm 705 \mathrm{~m})$, G. GajahMungkut $( \pm 737 \mathrm{~m})$. Subzona Baturagung ini membentuk relief paling kasar dengan sudut lereng antara $10^{\circ}-30^{\circ}$ dan beda tinggi $200-700$ meter serta hampir seluruhnya tersusun oleh batuan asal gunungapi.

Subzona Wonosari merupakan dataran tinggi $( \pm 190 \mathrm{~m})$ yang terletak di bagian tengah Zona Pegunungan Selatan, yaitu di daerah Wonosari

\footnotetext{
${ }^{*}$ Correspondence: sismanto@mail.ugm.ac.id

Laboratorium Geofisika, Departemen Fisika, Fakultas Matematika dan IImu Pengetahuan Alam, Universitas Gadjah Mada, Yogyakarta,

Full list of author information is available at the end of the article

${ }^{\dagger}$ Equal contributor
}

dan sekitarnya. Dataran ini dibatasi oleh Subzona Baturagung di sebelah barat dan utara, sedangkan di sebelah selatan dan timur berbatasan dengan Subzona Gunung Sewu. Aliran sungai utama di daerah ini adalah K. Oyo yang mengalir ke barat dan menyatu dengan K. Opak. Sebagai endapan permukaan di daerah ini adalah lempung hitam dan endapan danau purba, sedangkan batuan dasarnya adalah batugamping.

Subzona Gunung Sewu merupakan perbukitan dengan bentang alam karts, yaitu bentang alam dengan bukit-bukit batugamping membentuk banyak kerucut dengan ketinggian beberapa puluh meter. Di antara bukit-bukit ini dijumpai telaga, luweng (sink holes dan di bawah permukaan terdapat gua batugamping serta aliran sungai bawah tanah. Bentang alam karts ini membentang dari pantai Parangtritis di bagian barat hingga Pacitan di sebelah timur.

Diantara Parangtritis dan Pacitan merupakan tipe karts (kapur) yang disebut Pegunungan Seribu atau Gunung Sewu, dengan luas kurang lebih $1400 \mathrm{~km}^{2}$. Sedangkan antara Pacitan dan Popoh selain tersusun oleh batugamping(limestone) juga tersusun oleh batuan hasil aktifitas vulkanis berkomposisi asam-basa antara lain granit, andesit dan dasit [6].

Bantul merupakan daerah yang berada pada dominasi struktur geologi Young Merapi Volcanic (Quartenary) di bagian tengan dan Volcanic (Miocine dan oligo-miocine). Secara struktural daerah Bantul diapit oleh bukit patahan, yaitu lereng barat pegunungan Batur Agung pada bagian timur dan bagian barat beruka bekas laguna. Wilayah yang berada pada apitan bukit patahan ini disebut dengan Graben. Ini terbentuk dari proses diatrofisme tektonisme yang dipengaruhi oleh aktivitas gunung Merapi dan gunung Api tua.

Jenis batuan yang terdapat di kabupaten Bantul secara umum terdiri dari tiga jenis batuan yaitu batuan beku, batuan sedimen, dan endaoan. Berdasarkan sifat-sifat batuannya dapat diperinci menjadi tujuh formasi yaitu formasi Yogyakarta (46\%), Formasi Sentolo (18\%), Formasi Sambipitu (3\%), Formasi Semilir Nglanggaran (24\%), Formasi Wonosari (8\%), dan gumuk Pasir (1\%). Dari informasi geologi di sepanjang pesisir pantai Bantul struktur geologi nya berupa sedimentary young merapi volcanic tetapi sudah tertutupi oleh sedimentasi dari pasir besi yang berukuran kecil akibat proses pelapukan (weathering) dan transportasi. Di bagian utara dari subsatuan Gumuk Pasir terdapat subsatuan dataran Aluvial (Qa) [4]. Pantai yang tersusun oleh material berukuran halus yang berasak daru subsatuan gumuk pasir yang terpengaruhi oleh kegiatan angin. 


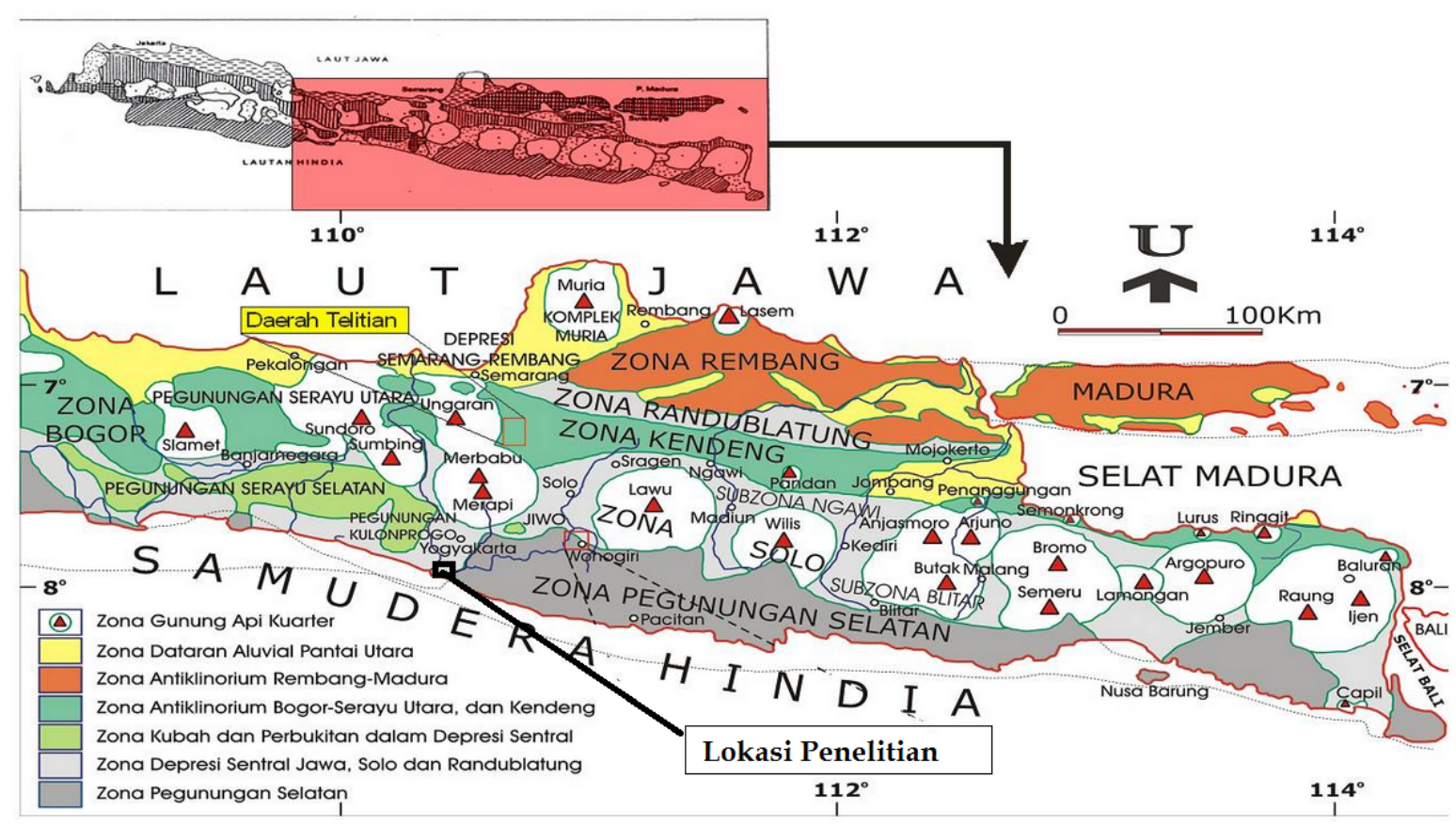

Gambar 1: Peta fisiografi daerah Jawa Tengah dan

Jawa Timur [6]

Selain itu terdapat kawasan ekosistem gumuk pasir yang terletak di Daerah Parangtritis, sekitar 28 kilometer dari kraton Yogyakarta ke arah selatan. Sebelah selatan berbatasan dengan Samudera Hindia, sebelah barat berbatasan dengan Kali Opak. Sebelah utara berbatasan dengan Desa Domotirto Kecamatan Pundong, sedang sebelah timur kecamatan Panggang, Kabupaten Gunungkidul. Di desa itu terdapat sekitar 190 buah gumuk pasir yang terdiri dari jenis Barchan, Longitudinal,Parabolik dan Sisir. Masing-masing jenis gumuk pasir tersebut mempunyai cara pembentuk yang berbeda, dan dikontrol oleh faktor-faktor yang berbeda-beda pula.

Gumuk pasir merupakan akumulasi pasir lepas berupa gundukan teratur hasil kerja dan pengaruh komponen-koponen : (1) jumlah pasir yang diendapkan teratur ke laut, (2) ombak yang memindahkan pasir dari laut ke darat,(3) intensitas sinar matahari yang mengeringkan pasir di pantai, (4) intensitas dan kemenerusan angin yang memindahkan pasir, (5) tebing penghambat gerak angin dan sebaran pasir, (6) vegetasi, dan (7) dinamika budaya masyarakat.

Di Parangtritis terdapat sekitar 190 bentuk gumuk pasir, yang terdiri dari jenis-jenis Barchan 70 buah, Longitudinal 80 buah, Parabolik 30 buah dan Sisir 10 buah. Masing-masing bentuk tersebut mempunyai cara dan faktor pengontrol pembentukan yang berbeda. Bentuk Parabolik dan Sisir dipengaruhi oleh vegetasi yang memotong arah angin sehingga kecepatan angin di belakang vegetasi kurang. Bentuk Barchan dan Longitudinal dipengaruhi oleh aktivitas angin yang bertiup kuat. Barchan mempunyai proses pembentukan meranik. MUlanya terbentuk gumuk pasir longitudinal yang mempunyai sumbu panjang sejajar dengan arah angin. Berikutnya tubuh gumuk pasir semakin tinggi. Kondisi tersebut menyebabkan terjadinya perputaran air di belakang gumuk, yang menyebabkan terjadinya penggerusan di belakang gumuk. Penggerusan yang semakin kuat menjadi penggerusan semakin intensif sehingga dimensi lebar seimbang dengan dimensi panjang.

Gumuk pasir Parangtritis dapat dikelompokkan menjadi dua kelompok besar : pasif dan aktif. Gumuk pasir aktif menempati sisi timur pada luasan sekitar 70 hektar. Di sini proses-proses pembentukan gumuk pasir Longitudinal dan Barchan oleh aktivitas angin yang bertiup kuat dapat diamati dan dipelajari dengan baik, misalnya struktur pengendapan permukaan riple mark. Gumuk pasir pasif menempati sisi barat dan seatan sampai muara Kali Opak pada luasan sekitar 175 hektar. Di sini berkembang gumuk pasir parabolik dan sisir. Vegetasi yang memotong arah angin tenggara-barat lau menyebabkan berkurangnya kecepatan angin di belakang vegetasi sehingga terjadi sedimentasi. 


\section{Konsep Magnetik}

Secara teoritis, medan magnet utama bumi disebabkan, oleh sumber dari dalam dan luar bumi. Dalam survei dengan metode geomagnet yang menjadi target dari pengukuran adalah variasi medan magnetik yang terukur di permukaan (anomali magnetik). Secara garis besar anomali medan magnetik disebabkan oleh medan magnetik remanen dan medan magnetik induksi. Medan magnet remanen mempunyai peranan yang besar terhadap magnettisasi buatan yaitu pada besar dan arah medan magnetiknya serta berkaitan dengan peristiwa kemagnetan sebelumnya sehingga sangat rumit untuk diamati. Anomali yang diperoleh dari survei merupakan hasil gabungan medan magnetik remanen dan induksi, bila arah medan magnet remanen sama dengan arah medan magnet induksi maka anomalinua bertambah besar. Demikian pula sebaliknya, dalam survei magnetik efek medan remanen akan diabaikan apabila anomali medan magnetik kurang dari $25 \%$ medan magnet utama bumi [5], sehingga dalam pengukuran medan magnet berlaku:

$$
\Delta T=T_{o b s}-T_{I G R F} \pm T_{V H}
$$

dengan $\Delta T$ adalah medan magnet hasil koreksi, $T_{o b s}$ adalah medan magnet observasi hasil pengukuran lapangan. $T_{I G R F}$ adalah medan magnet referensi berdasarkan IGRF. $T_{H V}$ adalah koreksi medan magnet harian.

\section{Konsep Geolistrik/Resistivitas}

Metode resistivitas melibatkan pengukuran resistivitas semu tanah/batuan sebagai fungsi kedalaman dan posisi. Arus disuntikkan melalui elektroda arus dan beda potensial diukur di permukaan dengan menggunakan sepasang eletroda beda potensial. Konfigurasi turunan metode geolistrik yang digunakan adalah konfigurasi schlumberger atau geolistrik sounding. Dalam resistivitas sounding dengan memvariasi jarak antara elektroda arus dan beda potensial akan menghasilkan informasi mengenai resistivitas bawah permukaan sebagai fungsi kedalaman [5]. Variasi resistivitas dan kedalaman dimodelkan dengan menggunakan software IP2Win:

\section{Akuisisi Data}

Daerah penelitian berada di pantai Samas dan pantai Goa cemara Bantul, seperti yang disajikan pada gambar 2. Luas wilayah pengukuran geomagnetik yaitu $2,5 \times 1,5 \mathrm{~km}^{2}$, yang di bagi ke dalam 13 lintasan pengukuran, dengan spasi antara lintasan $200 \mathrm{~m}$, dan jarak antara titik pengukuran adalah 50m. Akusisi data dilakukan dari tanggal 9-21 februari 2016. Untuk pengukuran data geolistrik diperoleh sejumlah titik pengukuran 29 titik di luasan area seluas $1 \times \mathrm{km}^{2}$ dengan panjang lintasan tiap titik pengukuran adalah $300 \mathrm{~m}$. Sebaran titik titik ukuranya disajikan pada gambar 3. Untuk keperluan interpretasi dilakukan 3 titik penggalian (test pit) sedalam $2 \mathrm{~m}$, guna memahami lithologi jenis pasir besinya.

\section{Hasil dan Pembahasan \\ 3.1. Test Pit (Data Galian)}

Data galian (test pit) titik pertama berada pada posisi 8.00027 LS 110.25274 BT. Penggalian dilakukan pada daerah pantai dengan ukuran lubang galian yaitu panjang $2 \mathrm{~m}$ dan lebar $1 \mathrm{~m}$ dengan kedalaman $1 \mathrm{~m}$. Penggalian dilakukan dengan menggunakan cangkul dan sekop. Hasil penggalian pada titik 1, 2 dan 3 disajikan pada gambar 4 . Berdasarkan gambar 4A tersebut nampak bahwa pembentukan endapan pasir besi di wilayah ini pembentukannya dipengaruhi oleh lingkungan darat dan lingkungan laut (Transitional Placer), yang mana faktor pengontrol dari pembentukannya oleh gelombang laut, pengaruh pasang surut, dan energi angin. Pada titik 1 ini menunjukkan bahwa tipe endapannya Pasir pantai/Strandline atau dapat juga dikatakan Dune/aeolean. Pembentukan pasir besi berupa perlapisan dari selatan mengarah utara dan bentuk perlapisan (garis merah).

Data galian (test pit) titik kedua berada pada posisi S7.99761 E110.25144. Penggalian dilakukan pada panjang $2 \mathrm{~m}$ dan lebar $1 \mathrm{~m}$ dan kedalaman $1 \mathrm{~m}$. Pada titik 2 galian (test pit) ini kandungan pasir besi lebih tinggi dibandingkan pada titik 1 . Nampak pada gambar 4B, bahwa pembentukan pasir besi perlapisan yang mengarah kebarat dari timur dalam bentuk perlapisan. Data galian titik ketiga berada pada posisi 7.99880 LS 110.24894 BT. Hasil penggalian pada titik 3 disajikan pada gambar $4 \mathrm{C}$. Nampak bahwa pembentukan endapan pasir besi di wilayah ini pembentukannya dipengaruhi juga oleh lingkungan darat dan lingkungan laut, yang mana faktor pengontrol dari pembentukannya oleh gelombang laut, pengaruh pasang surut, dan energi angin. Pada titik 3 galian test pit dengan panjang 2 $\mathrm{m}$ dan lebar $1 \mathrm{~m}$ dengan kedalaman $2 \mathrm{~m}$ menunjukan kandungan pasir besi berada sampai kedalaman $1 \mathrm{~m}$.

\subsection{Magnetik}

Dari hasil koreksi medan magnet harian dan koreksi IGRF maka di peroleh nilai anomali medan magnet di topografi seperti yang disajikan pada gambar 5. Dengan nilai IGRF pada tahun 2016 di daerah penelitian yaitu $45109 \mathrm{nT}$. Koreksi ini dilakukan untuk menghilangkan pengaruh medan magnet utama Bumi. 


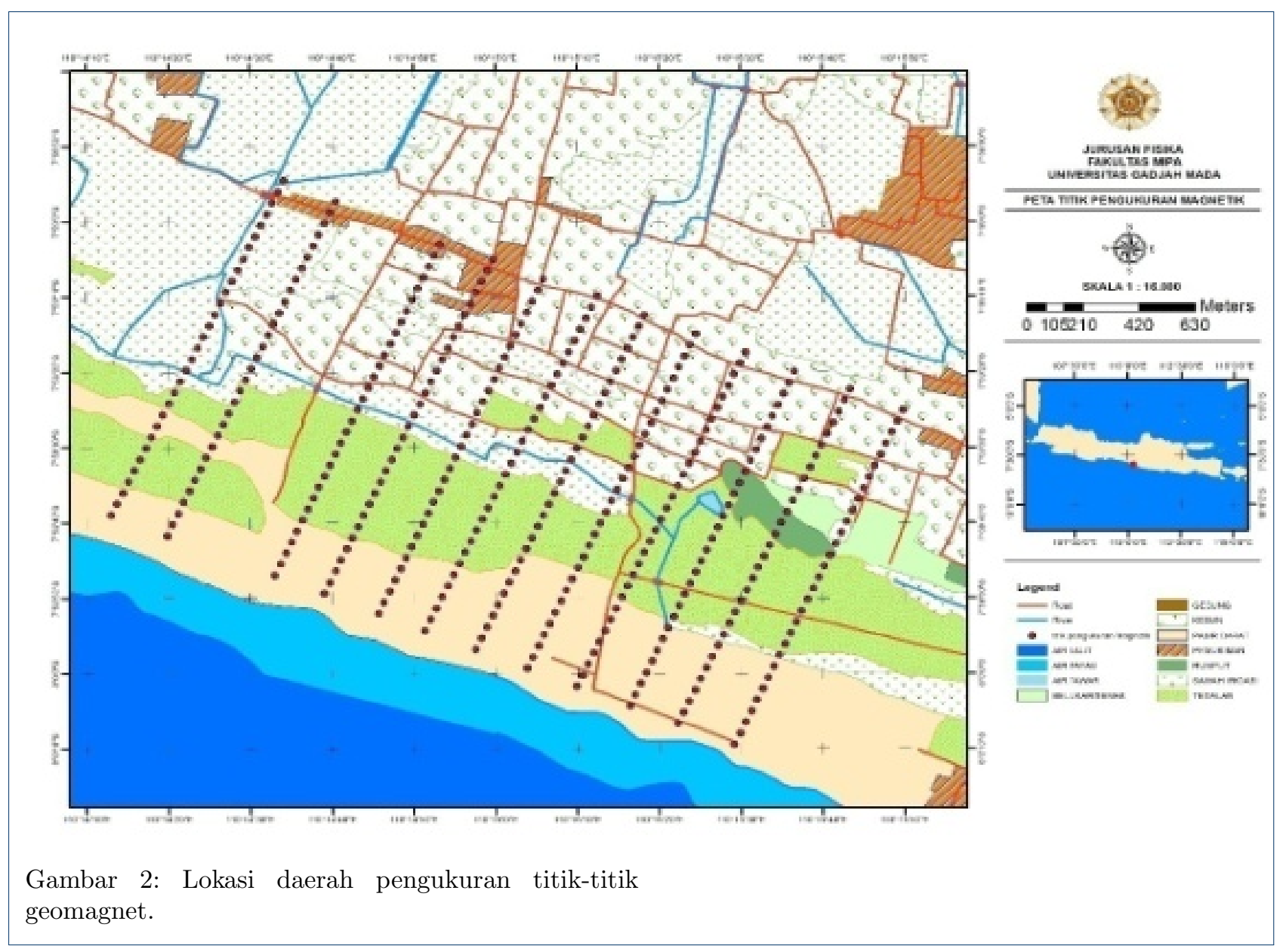

Kemudian dilakukan Reduksi ke kutub, karena anomali target medan magnetik yang berupa dipole selalu bersuperposisi dengan sumber anomali. Untuk melokalisasi daerah - daerah dengan anomali maksimum yang menjadi target sumber anomali, tahapan ini perlu dilakukan untuk mempermudah prosess interpretasi. Reduksi ke kutub ini dilakukan dengan cara memasukan nilai inklinasi dan deklinasi daerah tersebut pada persamaan yang diprogramkan oleh software Oasis Montai., hasilnya seperti yang di perlihatkan pada gambar 6 .

Berdasarkan data anomali magnetik yang di peroleh dari hasil pengukuran di lapangan menunjukkan bahwa daerah pantai Samas dan pantai Goa Cemara merupakan daerah yang memiliki anomali medan magnetik total sangat besar. Intensitas medan magnetik total di daerah ini rata - rata $43600 \mathrm{nT}$ sampai 46300 nT. Sehingga setelah dilakukan koreksi harian dan koreksi IGRF, di peroleh dara anomali medan magnetik total dengan nilai yang berkisaran antara - 1275,4 nT sampai 1092,2 nT. Dari peta kontur anomali dapat dilihat bahwa nilai positif lebih dominan dari pada nilai negatif, terutama terlihat jelas pada peta kontur anomali magnetik setelah dilakukan proses reduksi ke kutub. Jika ditinjau menurut kenampakan di lapangan, hal ini terjadi karena lokasi penelitian berada di kawasan yang lapisan tanahnya pasir yang banyak mengandung mineral pasir besi, sehingga nilai susepbilitas magntiknya meningkat dan relatif lebih besar. Analisis peta kontur anomali medan magnet total hasil reduksi ke kutub di overlay dengan peta geologi pada daerah penelitian, karena pada analisis juga mempertimbangkan informasi geologi pada daerah tersebut. Berdasarkan peta hasil overlay (Gambar 7), menunjukkan bahwa di daerah penelitian di dominasi oleh Endapan Aluvium (Qa) dan endapan Gunung Merapi Muda (Qmi) yang berumur Kuarter. Endapan Gunung Merapi Muda tersebar di wilayah bagian utara, sedangkan Endapan Aluvium banyak tersebar dibagian selatan.

Hasil overlay yang ditunjukkan pada Gambar 7 memperlihatkan adanya sebaran anomali medan magnet tinggi dan rendah di daerah penelitian. Anomali tinggi hampir merata ada di seluruh daerah penelitian ini disebabkan karena daerah penelitian di apit oleh dua kali besar yaitu Kali Progo dan Kali 


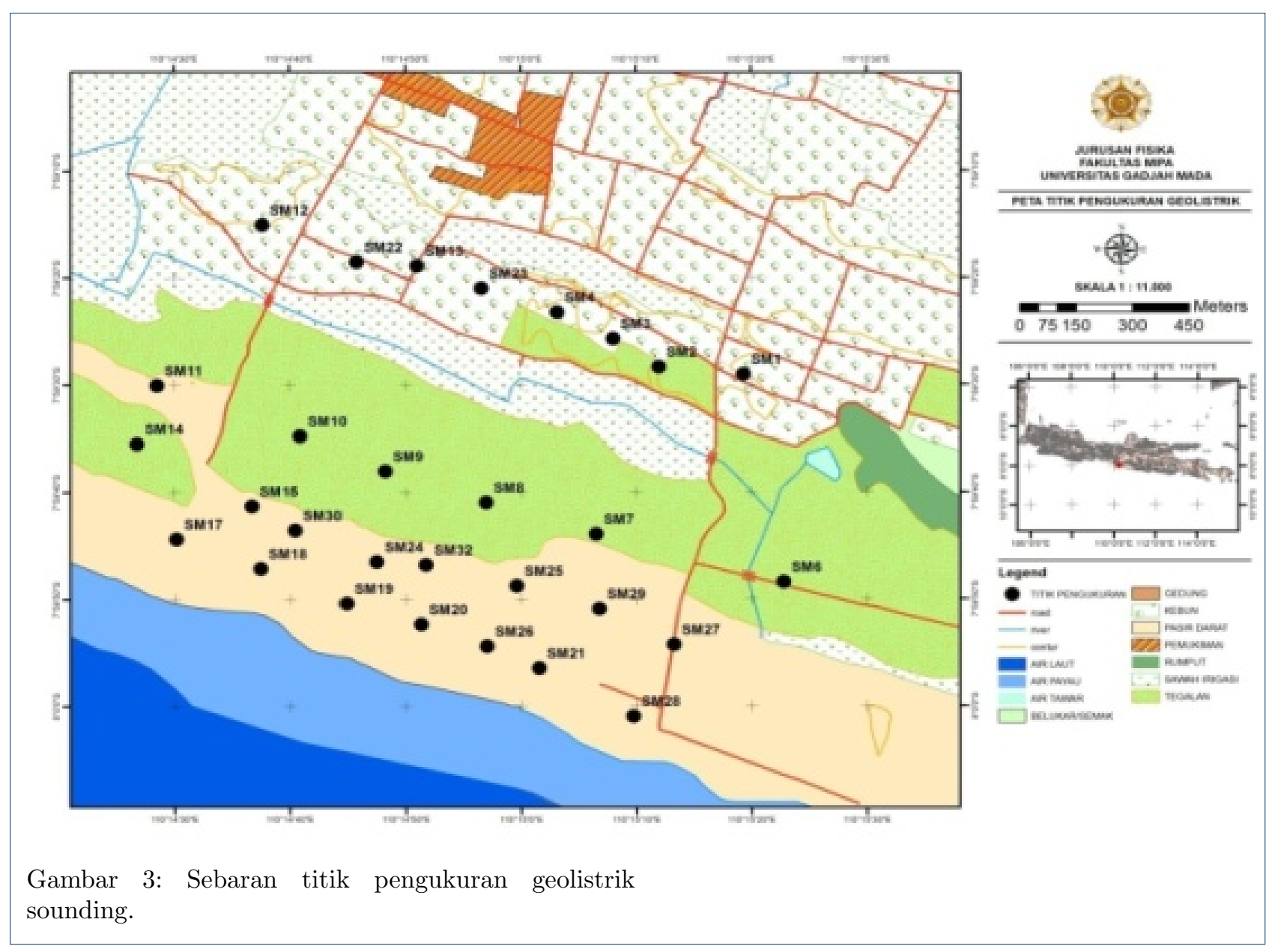

Opak yang membawa mineral - mineral dari endapan Gunung Api.

\subsection{Geolistrik}

Pengukuran metode geolistrik dalam penelitian ini dilaksanakan sebanyak 29 titik pengukuran dengan menggunakan konfigurasi Schlumberger, pengolahan data dengan menggunakan software IP2win. Beberapa contoh hasilnya pemrosesan diberikan pada gambar 8 . Gambar 8.(a) merupakan tampilan hasil pengolahan data menggunakan software IP2win, pada titik pengukuran 12 nilai resistivitas $1474 \Omega m$ dengan estimasi ketebalan 2,46 m pada kedalaman 2,46 m diidentifikasi sebagai pasir halus yang bersifat lepas. Adapun pada kedalaman 2,46 m hingga 12,9 m dengan nilai resistivitas $176-69,2 \Omega m$ diidentifikasi sebagai pasir sedang - hingga pasir kasar yang mengandung pasir besi. Pada kedalaman 12,9 $\mathrm{n}$ hingga 50,8 m dengan nilai resistivitas $134 \Omega m$ diduga berupa pasir kasar yang berupa pasir besi. Pada kedalaman 50,8 n hingga 98,1 m dengan resistivitas $13,1 \Omega m$ yang diduga lempung pasiran. Titik pengukuran ini berada jauh dari bibir pantai.
Gambar 8.(b) merupakan hasil titik pengukuran 22 nilai resistivitas $1593 \Omega m$ dengan estimasi ketebalan 2,06 $\mathrm{m}$ pada kedalaman 2,06 $\mathrm{m}$ diidentifikasi sebagai pasir halus yang bersifat lepas yang mengandung pasir besi. Adapun pada kedalaman 2,06 m hingga $18,6 \mathrm{~m}$ dengan nilai resistivitas 52,4 hingga 85,6 $\Omega m$ diidentifikasi sebagai pasir lempungan. Pada kedalaman 18,6 $\mathrm{m}$ hingga 48,5 $\mathrm{m}$ dengan nilai resistivitas 24,7 $\Omega m$ diduga berupa lempungan pasiran. Titik pengukuran ini berada jauh dari bibir pantai.

Gambar 8.(c) merupakan hasil titik pengukuran 13 yang berada jauh dari bibir pantai pada line 1 . Hasilnya menunjukkan pada kedalaman 0 - 4,82 m dengan nilai resistivitas yaitu $667 \Omega m$ diindikasikan sebagai pasir halus yang mengandung pasir besi. Pada kedalaman 4,82 n - 6,91 m nilai resistivitas $322 \Omega m$ yang diindikasikan pasir halus - sedang yang mengandung pasir besi. Pada kedalaman 24,4 m - 69,9 $\mathrm{m}$ dengan resistivitas berkisar antara $65,9 \Omega m-26,4$ $\Omega m$ diindikasikan sebagai pasir lempungan.

Gambar 8.(d) merupakan hasil titik pengukuran 23 yang berada jauh dari bibir pantai pada line 1. Hasil 
pengolahan menunjukkan pada kedalaman 0 - 1,72 m dengan nilai resistivitas yaitu $1688 \Omega m$ diindikasikan sebagai pasir halus. Pada kedalaman 1,72 m - 28,4 m nilai resistivitas 301 - $364 \Omega m$ yang diindikasikan pasir halus - sedang yang mengandung pasir besi. Pada kedalaman 28,4 m - 47,9 m dengan resistivitas 20,4 $\Omega m$ diindikasikan sebagai lempungan pasiran. Pada titik pengukuran 23 kenampakan pasir besi di permukaan lebih sedikit jika dibandingkan dengan pengukuran di titik 13 yang sama-sama berada di line 1 .

Dari sejumlah 29 titik pengukuran dikorelasikan hasil interpretasinya (kedalaman, ketebalan dan sebaran batu pasirnya berdasarkan nilai resistivitas) dari beberapa titik dalam satu lintasan, diperoleh gambaran seperti yang disajikan pada gambar 9 untuk lintasan pertama, gambar 10 adalah lintasan ke dua, gambar 11 lintasan ketiga dan gambar 12 untuk lintasan ke empat.

Pada gambar 9 nampak bahwa kedalaman pasir besi pada lintasan pertama rata-rata sekitar $30 \mathrm{~m}$ dari permukaan yang terdiri dari pasir halus hingga pasir kasar dengan rentang resistivitas 250-1000 $\Omega m$. Posisi lintasan pertama berada jauh dari bibir pantai. Kedalaman pasir besi pada lintasan ke dua (gambar 10) rata-rata sekitar $20 \mathrm{~m}$ yang terdiri dari pasir halus hingga pasir kasar dengan rentang resistivitas 150-1600 $\Omega m$. Sedangkan untuk lintasan ke tiga (gambar 11) kedalaman pasir besi pada rata-rata sekitar $25 \mathrm{~m}$ yang terdiri dari pasir halus hingga pasir kasar dengan rentang resistivitas 100-1300 $\Omega m$. Lintasan ke empat (gambar 12) kedalaman pasir besi rata-rata sekitar $20 \mathrm{~m}$ yang terdiri dari pasir halus hingga pasir kasar dengan rentang resistivitas 100-1100 $\Omega m$. Semua kedalaman keberadaan batu pasir tersebut ditinjau dari permukaan setempat.

Total 29 data titik ukur atau ke empat lintasan tersebut yang diperoleh dari hasil pemrosesan resistivity digabung untuk menentukan besar cadangan volume dengan menggunakan software Rockworks 15. Untuk itu diperlukan 4 variabel yaitu bujur sebagai parameter $\mathrm{x}$, lintang sebagai parameter $\mathrm{y}$, kedalaman sebagai parameter $\mathrm{z}$ yang didapatkan dari pemrosesan IP2WIN dan parameter resistivitas $\rho$ di masing-masing titik pengukuran dan masing-masing kedalaman. Keempat variabel tersebut. Estimasi volume pasir besi yang didapatkan dari pengolahan dengan luasan 1 x $1 \mathrm{~km}$ dengan nilai resistivitas berkisar $300 \Omega m-3000 \Omega m$ adalah sebesar $53.237 .500 \mathrm{~m}^{3}$ seperti yang ditampilkan pada gambar 13.

\section{Kesimpulan}

a Dari hasil koreksi variasi harian dan koreksi IGRF di peroleh nilai anomali medan magnet total sebesar -1275,4 nT sampai 1092,2 nT di daerah penelitian. b Tumpang tindih (Overlay) peta geologi daerah penelitian dengan peta anomali magnet total reduksi ke kutub, terlihat bahwa anomali magnetik menyebar hampir merata di daerah penelitian, ini dikarenakan daerah penelitian berdekatan dengan S. Progo dan S. Opak, dimana material-material dan mineral-mineral pasir besi tertransportasi dan terendapkan di daerah penelitian melalui aliran sungai tersebut.

c Nilai resistivitas pasir besi berkisar dari $300 \Omega m$ $3000 \Omega m$

d Nilai resistivitas yang tinggi diindikasikan sebagai pasir halus yang banyak mengandung pasir besi, kedalaman dari pasir halus berkisar antara 0-5 m. Adapun pasir sedang hingga pasir kasar yang mengandung pasir besi berada pada kedalaman 5-20 m.

e Estimasi cadangan pasir besi pengukuran resistivitas dengan luas wilayah $1 \mathrm{~km}^{2}$ adalah sebesar $53.237 .500 \mathrm{~m}^{3}$

\section{Penulis}

Sismanto, Yuris Sutanto, Radjabal Akbar dan Syamsul Fala Alaidin

Dari :

Laboratorium Geofisika, Departemen Fisika, Fakultas Matematika dan Ilmu Pengetahuan Alam, Universitas Gadjah Mada

Alamat :

Kode pos 55281, Yogyakarta, Indonesia

email : sismanto@mail.ugm.ac.id

\section{Pustaka}

1. Anonim, 2014. Pasir Besi di Indonesia Geologi, Eksplorasi dan Pemanfaatannya. Badan Geologi, Bandung.

2. Harsolomekso, 1997. Ekskursi Geologi Jawa Tengah - Jawa Timur, Jurusan Teknik Geologi UGM, Program Pasca Sarjana.

3. Jensen, M., and Bateman, A.M., 1981. Economic Mineral Deposit. Canada: Jhon Wiley and Sons Inc.

4. Rahardjo, W., Sukandarrumidi and Rosidi, H.M.D., 1995. Peta Geologi Lembar Yogyakarta 1:100.000, edisi kedua, Pusat Penelitian dan Pengembangan Geologi, Bandung.

5. Telford, W. M, 1990. Applied Geophysics Second Edition. Cambridge University.

6. Van Bemmelen, R.W, 1949. The Geology of Indonesia Volume II, Economic Geology, Government Printing Office, The Hague, Netherlands 


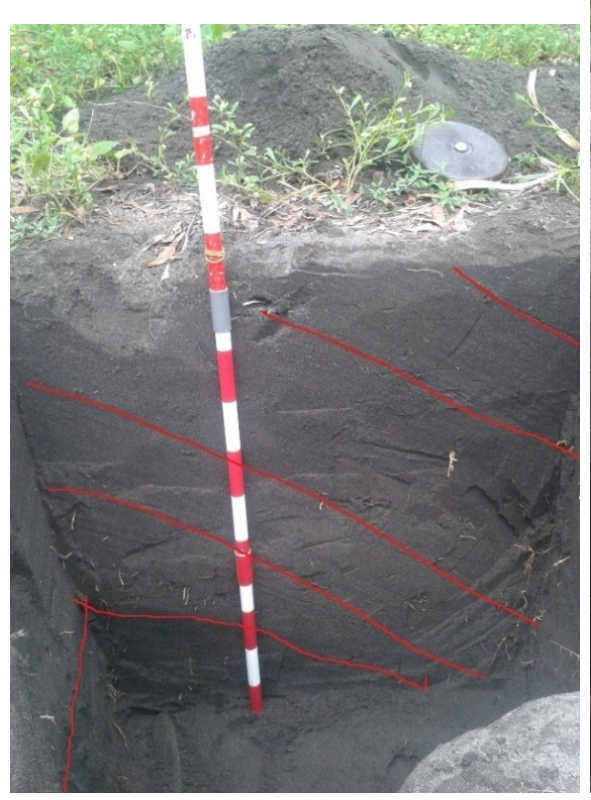

(a)

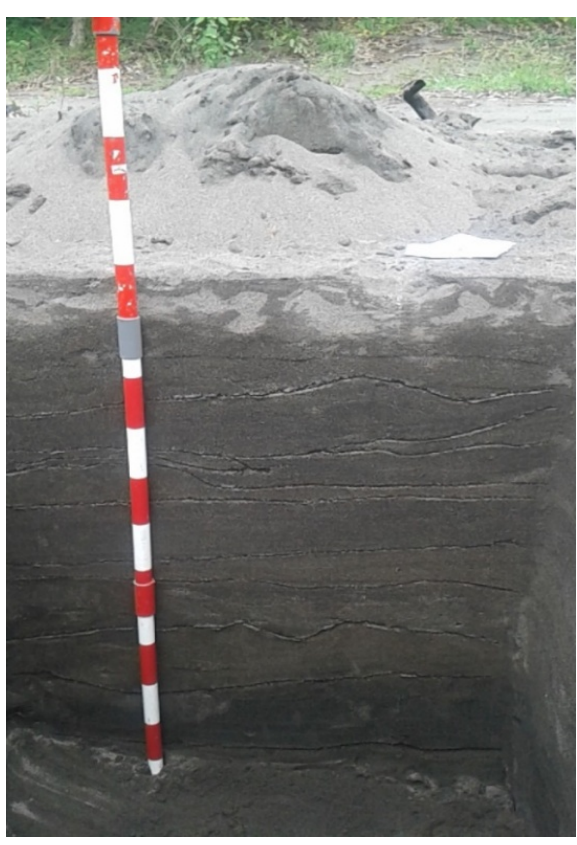

(b)

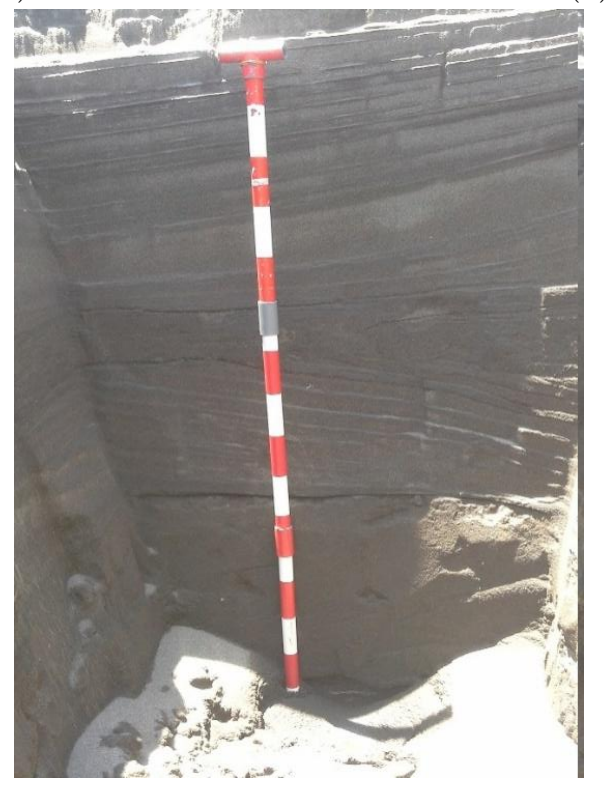

(c)

Gambar 4: A. Titik 1 galian (test pit) pasir besi 8.00027 LS 110.25274 BT.

B. Titik 2 galian pasir besi pada posisi $\mathrm{S} 7.99761$ E110.25144.

C. Titik 3 galian pasir besi pada posisi 7.99880 LS 110.24894 BT. 


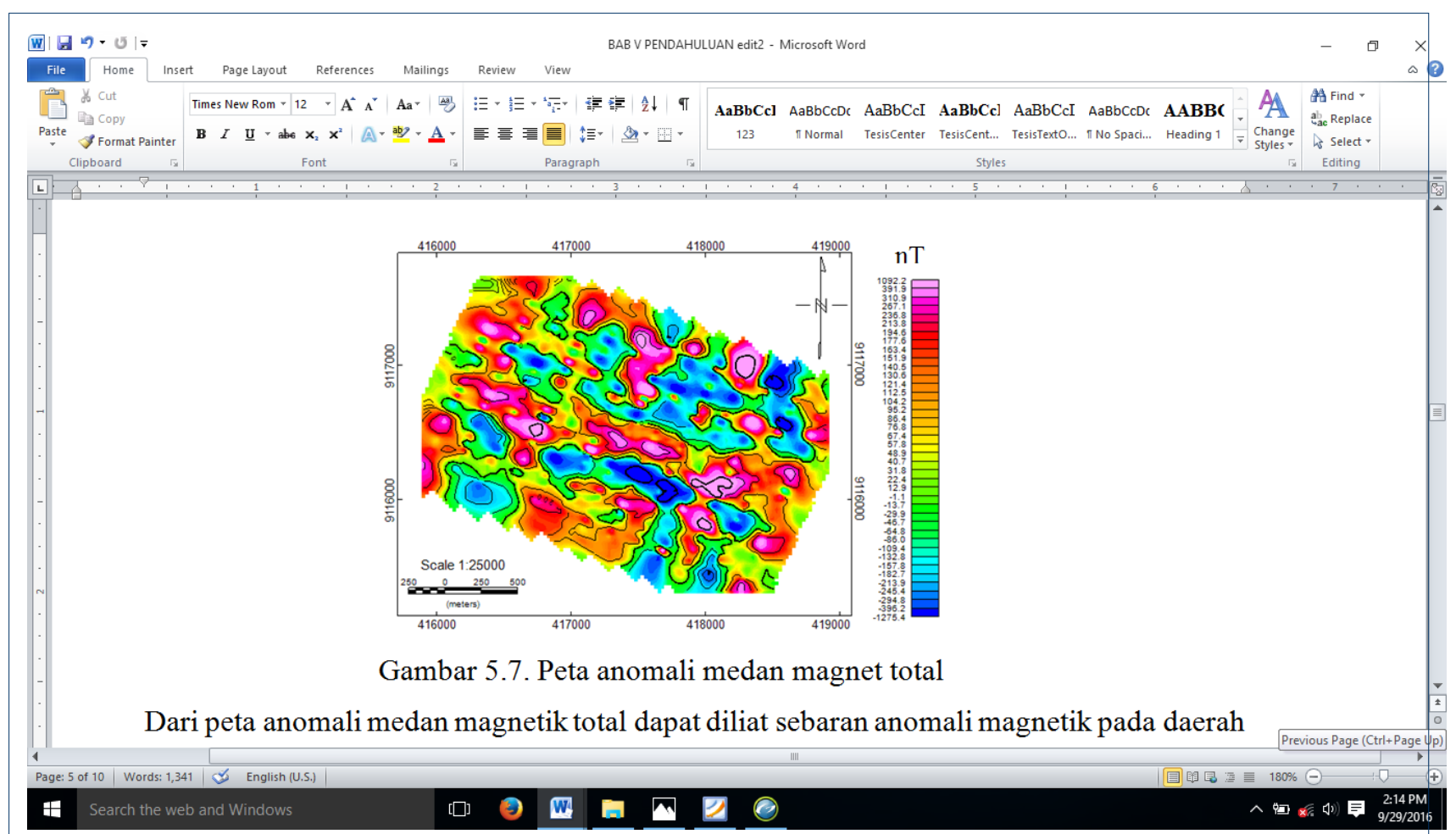

Gambar 5: Peta kontur anomali medan magnetik total setelah koreksi IGRF.

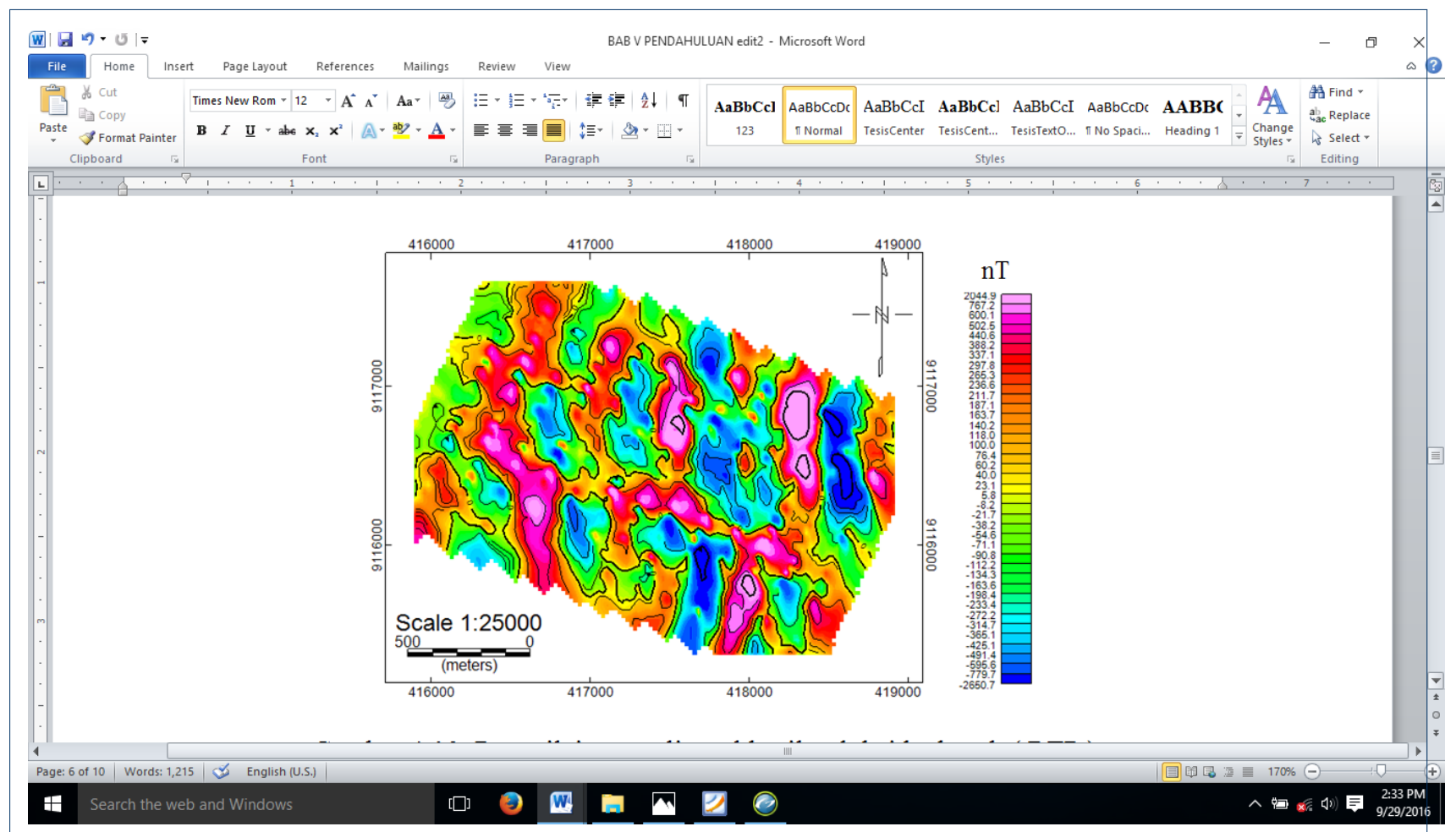

Gambar 6: Peta nilai anomali total hasil reduksi ke kutub. 


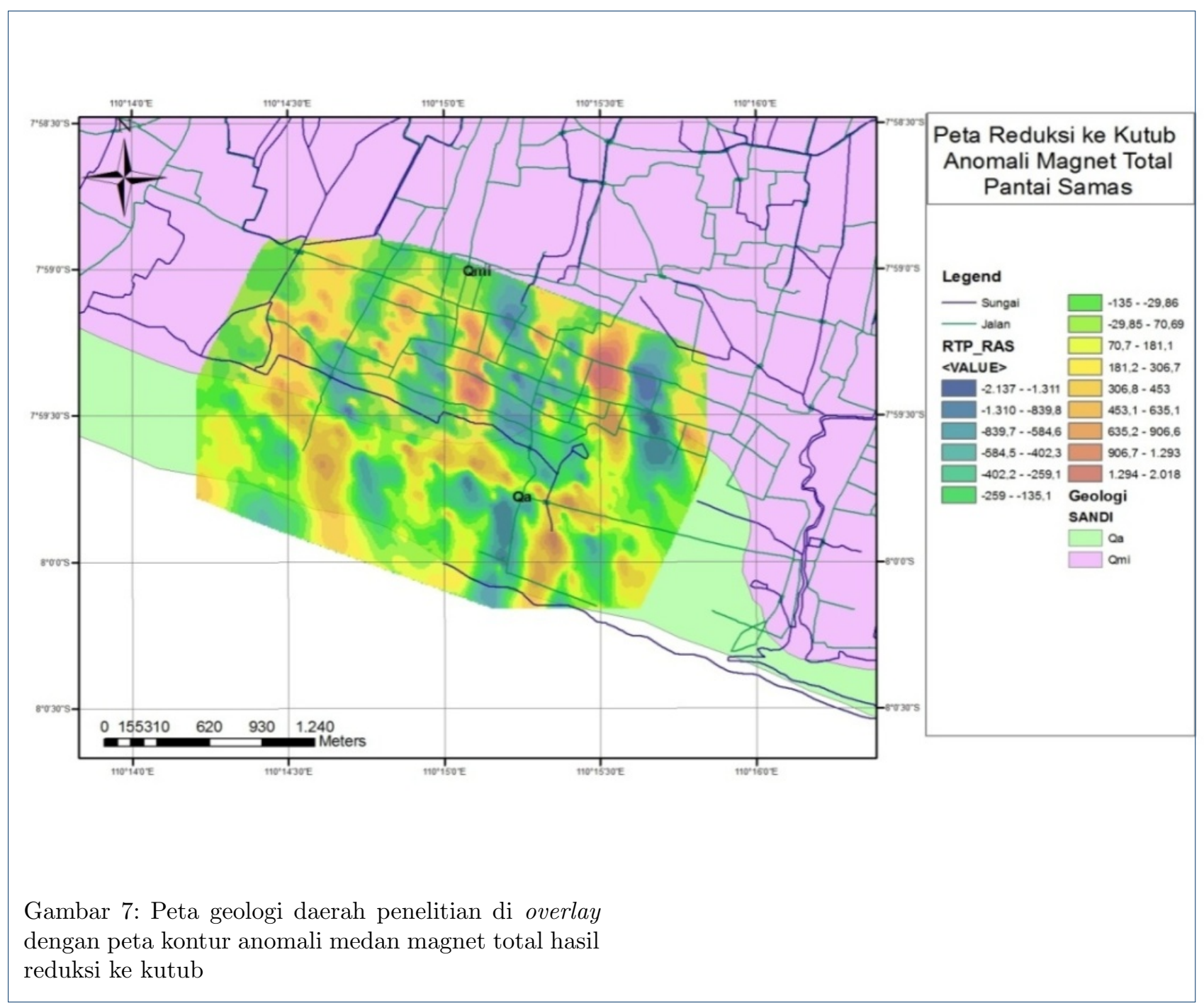




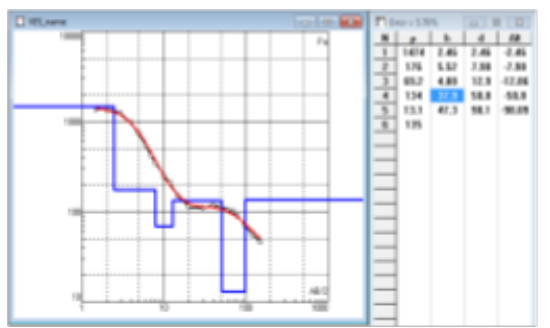

(a)

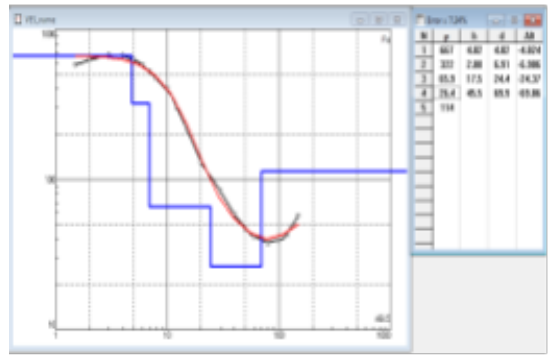

(c)

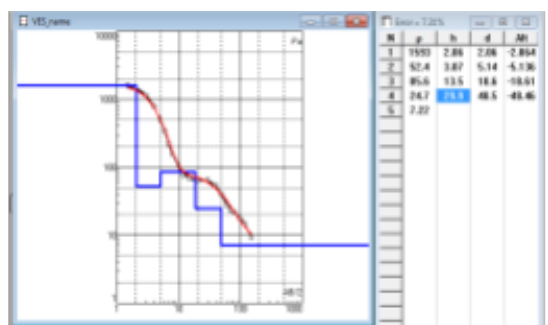

(b)

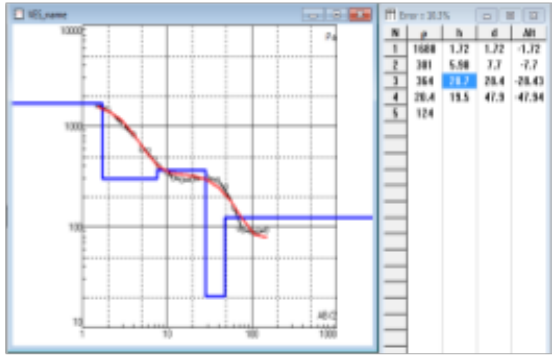

(d)

Gambar 8: Contoh hasil pemrosesan beberapa data Geolistrik, (a) titik pengukuran 12, (b) titik pengukuran 22 yang berada di line pertama, (c) titik pengukuran 13, (d) titik pengukuran 23 yang berada di line pertama.

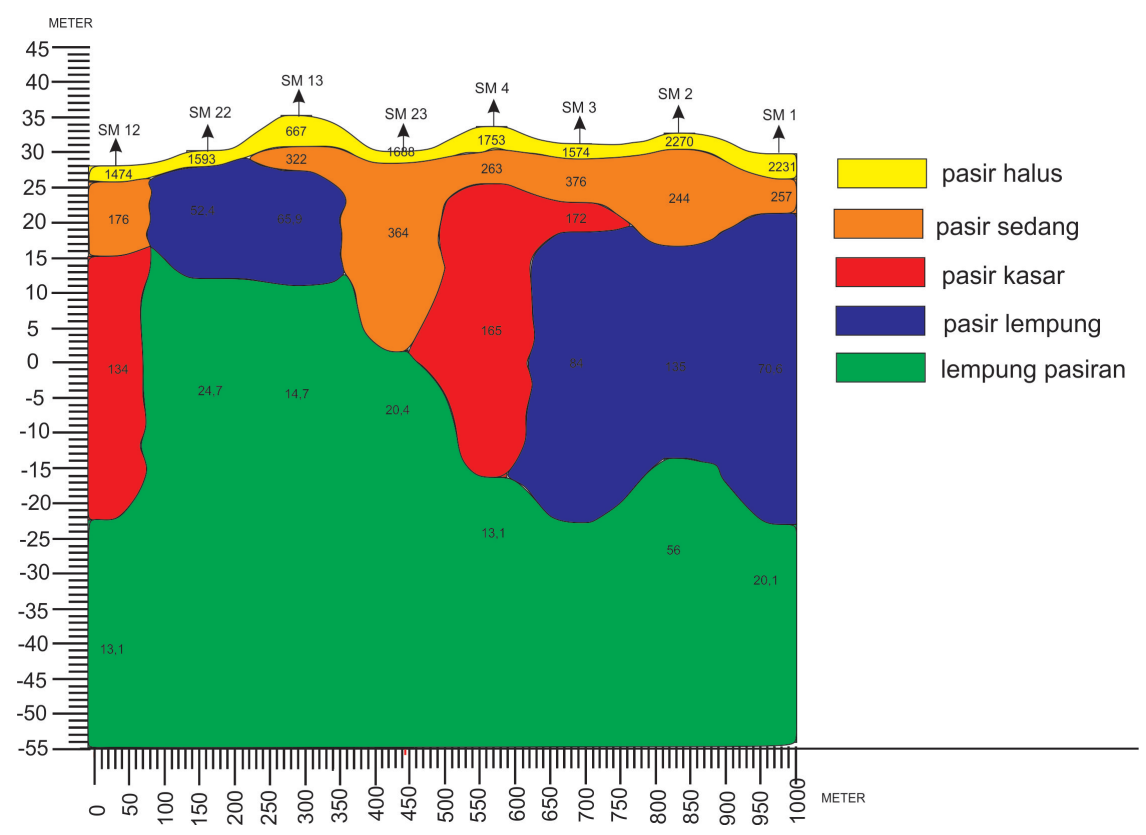

Gambar 9: Korelasi interpretasi bawah permukaan menggunakan data resistivitas lintasan satu yang terdiri dari titik-titik pengukuran $12,22,13,23,4$, 3,2 dan 1. 


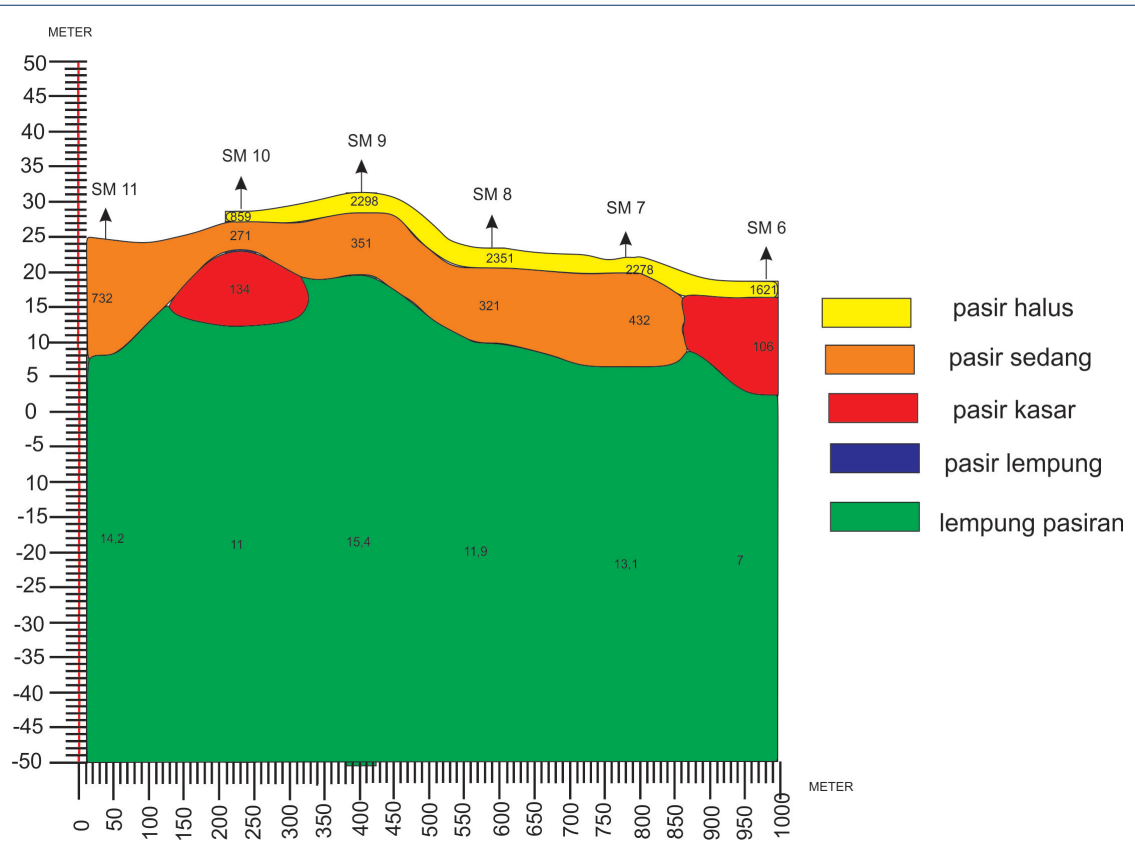

Gambar 10: Korelasi interpretasi bawah permukaan menggunakan data resistivitas lintasan dua yang terdiri dari titik-titik pengukuran $11,10,9,8,7$ dan 6.

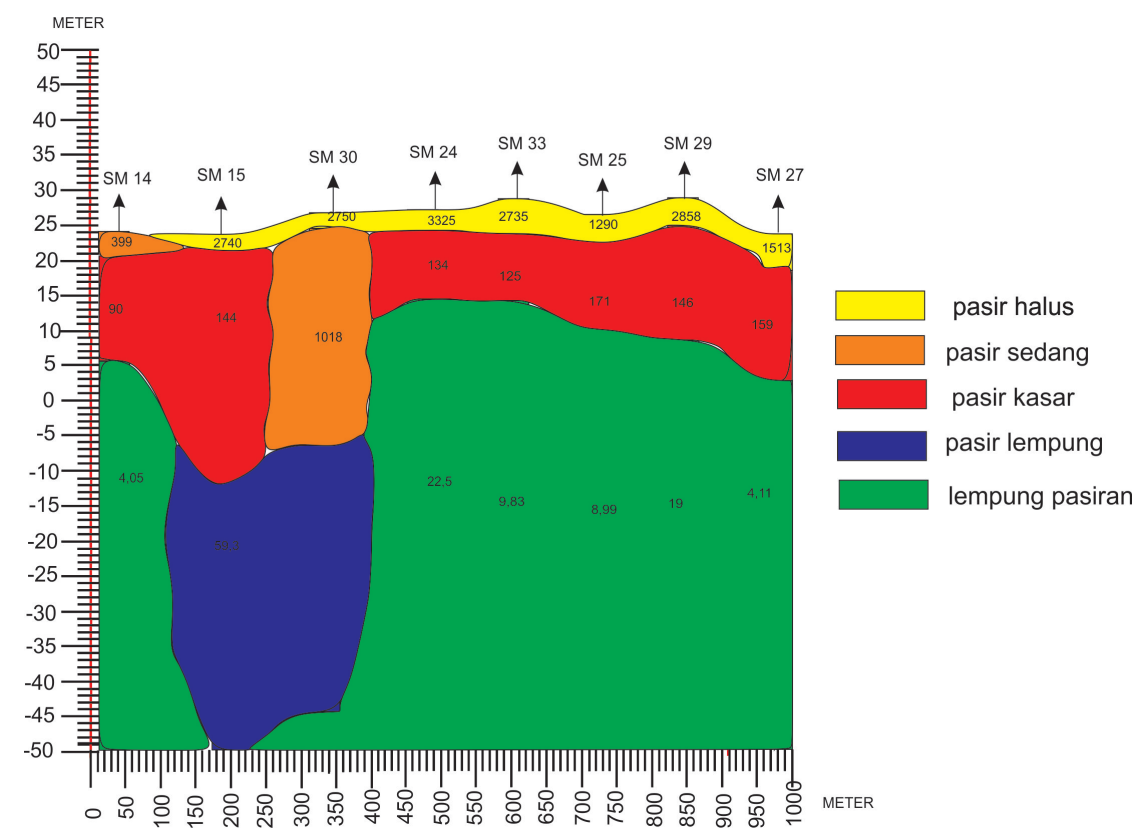

Gambar 11: Korelasi interpretasi bawah permukaan menggunakan data resistivitas lintasan tiga yang terdiri dari titik-titik pengukuran 14, 15, 30, 24, 33, 25, 29 dan 27. 


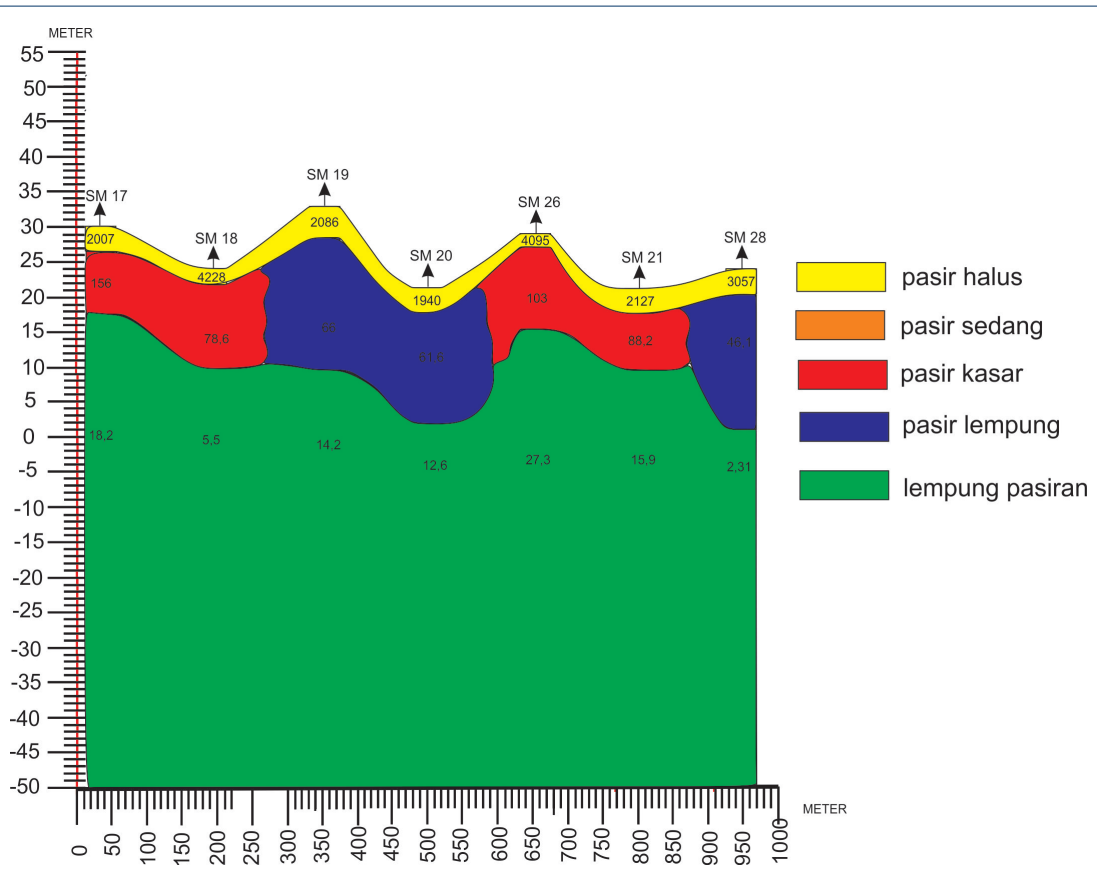

Gambar 12: Korelasi interpretasi bawah permukaan menggunakan data resistivitas lintasan empat yang terdiri dari titik-titik pengukuran 17, 18, 19, 20, 26, 21 dan 28

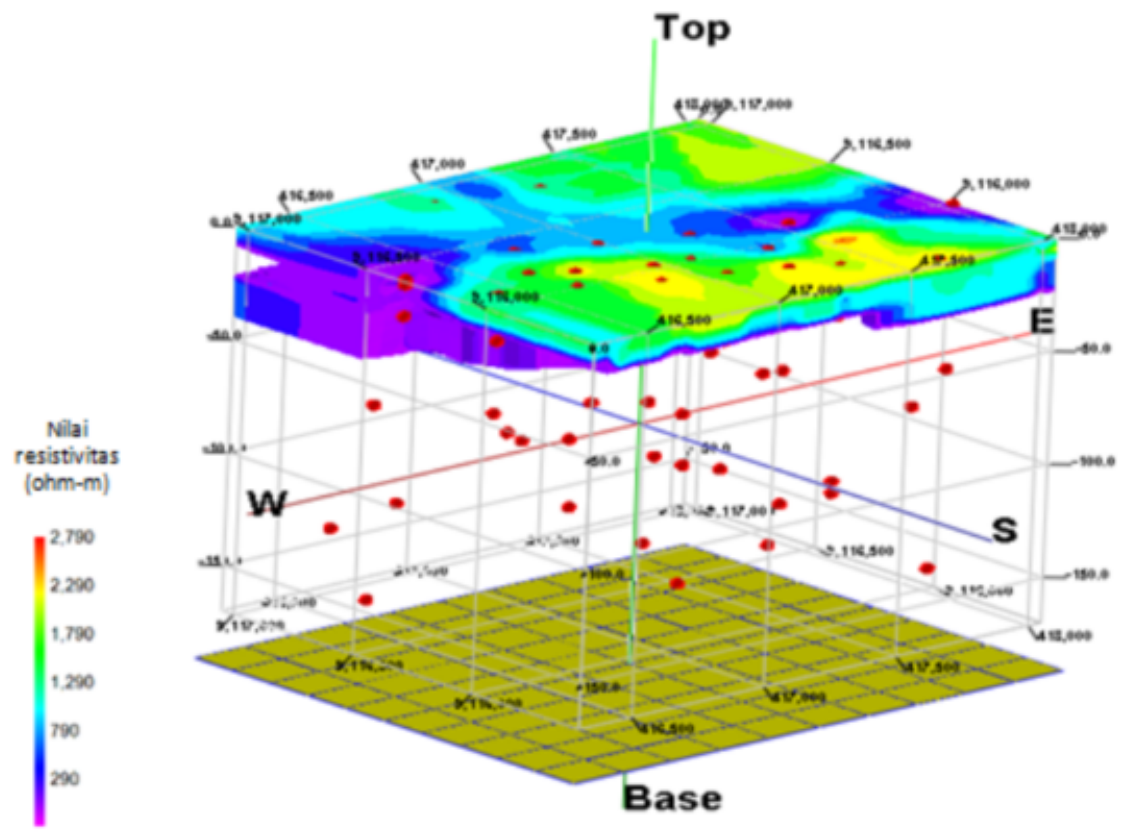

Gambar 13: Estimasi cadangan batu pasir dibatasi pada nilai resistivitas berkisar antara $300-1000 \Omega m$ dengan luas wilayah $1 \mathrm{~km}^{2}$ sebesar $53.237 .500 \mathrm{~m}^{3}$. 